\title{
Para um socratismo exemplar: Euclides de Mégara e a filosofia do Bem
}

\author{
For exemplar Socratism: Euclides of Megara and the philosophy of Good
}

\section{Cesar Augusto Mathias de Alencar ${ }^{1}$}

\begin{abstract}
1 Doutor pelo Programa de Pós-Graduação em Lógica e Metafísica - PPGLM/UFRJ. Mestre em Filosofia pelo Programa de Lógica e Metafísica (PPGLM). Graduado em Filosofia pela Universidade Federal do Rio de Janeiro (UFRJ). Professor Assistente do colegiado do curso de Filosofia da UNIFAP.

E-mail: cescama@gmail.com . Orcid: http://orcid.org/0000-0003-3145-0584
\end{abstract}

RESUMO: Pretendemos neste artigo apresentar uma aproximação crítica com relação à filosofia desenvolvida pelos chamados megáricos, em face sobretudo da figura de Euclides de Mégara como representante e líder dessa linhagem de pensamento. O enfoque será feito tendo em vista o tipo de filosofia exposta e praticada por Euclides, a partir das acusações que contra ela se fizeram denunciando-a como pura erística, ou seja, a disputa e o debate entre discursos com o único objetivo de obter vitória na argumentação. O que se constata em Euclides é a defesa da prática do debate com a finalidade de mostrar que o discurso é incapaz de dar conta da realidade, de um modo geral, e assim impossível de determinar, de um modo específico, o Ser e a Unidade que são a essência daquilo que organiza e move todas as coisas. Essa essência de ordem é desejável por ser boa, e o Bem se apresenta, assim, como fundamento da realidade. Os estudos sobre a tradição megárica dividem-se entre a influência dos eleatas e a influência de Sócrates. Faremos, desse modo, a defesa de que a filosofia de Euclides está afinada com o socratismo, conjugando de um modo exemplar aquilo que os eleatas haviam definido em relação ao Ser.

Palavras-chave: Socratismo, Ética, Dialética.

ABSTRACT: In this article we intend to present a critical approach to the philosophy developed by the socalled megarics, especially the person of Euclides of Megara as representative and leader of this line of thought. The focus will be on the kind of philosophy exposed and practiced by Euclides, based on the accusations against it as denouncing it as pure eristic, that is, dispute and debate between speeches with the sole aim of winning for the argument. What is evident in Euclid is the defense of the practice of debate in order to show that discourse is incapable of accounting for reality in general, and thus impossible to determine, in a specific way, Being and Unity which are the essence of what organizes and moves all things. This essence of order is desirable because it is Good, and Good is thus presented as the foundation of reality. Studies on the Megaric tradition are divided between the influence of the Eleatics and the influence of Socrates. In this way, we will defend Euclid's philosophy in line with the Socratism, combining in an exemplary way what the Eleatics had defined in relation to Being.

Keywords: Socratism, Ethics, Dialectics.

“Em seguida, quando me encontro nessa questão, saio fugindo, temendo um dia cair num palavreado vão e perder-me. Então, retornando para lá, às coisas que dissemos possuírem formas, passo o tempo ocupando-me delas." Platão, Parmênides 


\section{Introdução: Euclides e sua importância no grupo socrático}

Conta-nos a tradição, segundo a indicação recolhida por Diógenes Laércio, que os discípulos de Sócrates, após a condenação e morte do mestre, exilaram-se na casa de Euclides por algum tempo, temendo a força tirânica que então dominava a democracia em Atenas (DL, II.106, SSR, II.A.5). Em outra indicação, Platão é dito ter vinte anos à época do referido exílio em Mégara (DL, III.6; SSR, II.A.5). De fato, em duas ocasiões há esse testemunho da saída de companheiros de Sócrates da cidade de Atenas. A outra circunstância encontra-se nos pedidos de favor feitos por alguns socráticos ao tirano Dionísio I em Siracusa testemunhos que nos chegaram recheados de notícias sobre dissensões, sobretudo entre Platão e Aristipo.

Qualquer informação é preciosa, e temos com isso alguns elementos com os quais é possível traçar um esboço inicial da figura de Euclides. O primeiro elemento parece vir latente no testemunho citado, a nos dizer sobre a decisão de parte dos discípulos de Sócrates em se exilar a fim de conter aquela damnatio memoriae que possivelmente se insurgiria contra seus seguidores, em que Euclides é tomado como uma espécie de referência comum de proteção, ao menos circunstancial. Vale a ressalva de que a atitude de exílio dizia respeito mais propriamente àqueles que habitavam Atenas. Sabemos que este não era o caso de todos os companheiros de Sócrates, e a levarmos em conta o testemunho de Platão no Fédon (59c), é possível inferir que Aristipo estava ausente de Atenas à época da morte do mestre, como também estava ausente Xenofonte ${ }^{1}$.

Mas quem de fato foi Euclides, é pouco o que sabemos. Sobre ele, por exemplo, além de ter nascido em Mégara - cidade localizada no golfo de Egina, na Ática, próxima à ilha de Salamina - e ter pertencido ao círculo socrático, nos é narrado um acontecimento de inegável valor simbólico para a compreensão de sua personalidade e de sua dedicação a Sócrates. Quem nos narra o acontecido é o filósofo Tauro, diretor da escola platônica durante do século II d.C. e que foi o mestre de Aulo Gélio, autor do testemunho.

T1. philosophus Taurus, vir memoria nostra in disciplina platonica celebratus, cum aliis bonis multis salubribusque exemplis hortabatur ad philosophiam capessendam, tum vel maxime ista re iuvenum animos expergebat, Euclidem quam dicebat Socraticum factitavisse. "decreto", inquit, "suo Athenienses caverant, ut, qui Megaris civis esset, si intulisse Athenas pedem prensus esset, ut ea rea ei homini capitalis esset; tanto Athenienses" inquit, "odio flagrabant finitimorum hominum Megarensium. tum Euclides, qui indidem Megaris erat quique ante id decretum et esse Athenis et audire Socratem consueverat, postquam id decretum sanxerunt, sub noctem, cum advesperesceret, tunica longa muliebri indutus et pallio versicolore amictus et caput rica velatus e domo sua Megaris Athenas ad Socratem commeabat, ut vel noctis aliquo tempore consiliorum sermonumque eius fieret particeps, rursusque sub lucem milia passuum paulo amplius viginti eadem veste illa tectus redibat. at nunc," inquit, "videre est philosophos ultro currere, ut doceant, ad fores iuvenum divitum eosque ibi sedere atque opperiri ad meridiem, donec discipuli nocturnum omne vinum edormiant."

O filósofo Tauro, membro famoso da escola platónica atual, exortava os seus ouvintes a seguirem a filosofia com muitos exemplos apropriados e saudáveis; além disso, despertava o ânimo dos jovens sobretudo contando isto sobre Euclides, o socrático: "Os atenienses", dizia, "haviam estipulado um decreto que quem fosse cidadão de Mégara, caso fosse surpreendido pondo o pé em Atenas, se exporia

\footnotetext{
1 De fato, a mútua referência ou ausência de menções entre os socráticos é um problema à parte, para o qual remetemos às indicações feitas por MÁRSICO (2010). Aqui, vale lembrar a dúvida lançada por DIÓGENES LAÉRCIO, para quem a ausência de Aristipo na lista do Fédon de Platão (59c) foi mais uma calúnia que um testemunho (DL III.36; SSR, IV.A.15).
} 
por essa ação à pena capital; tanto", acrescentou, "era o ódio que os atenienses alimentavam contra seus vizinhos de Mégara. Mas Euclides, que habitava precisamente em Mégara e antes deste decreto tinha o costume de viajar a Atenas a fim de seguir as lições de Sócrates, depois da sanção deste decreto, seguia tarde, no momento em que caía a noite, coberto com uma túnica de mulher, envolto em um manto colorido, a cabeça coberta com um véu, saía de sua casa em Mégara até a Atenas de Sócrates, para participar, ainda que fosse por uma parte da noite, de suas deliberações e das conversações que ali se desenrolavam. Depois, ao alvorecer do dia, voltava a viajar em sentido contrário, um pouco mais de vinte milhas, sempre coberto com a mesma roupa. Ao menos agora", disse, "vê-se os filósofos correrem às portas dos jovens ricos a fim de lhes ensinarem, ali sentados a esperar até que ao meio-dia seus alunos acordem de uma noite toda regada a vinho. (AULO GELIO [Noites Aticas, VII.10.1-5] apud SSR, II.A.2)

O referido decreto, conhecido como "decreto megárico", teve lugar no contexto da guerra do Peloponeso, quando os ânimos entre Atenas e Mégara haviam se acirrado em torno da expansão ateniense que acabou por impor à cidade de Euclides um bloqueio econômico contra o qual Esparta, que liderava a Liga do Peloponeso, foi chamada por Mégara a intervir ${ }^{2}$. Esse evento ocorreu em 432 a.C. e serve como um bom parâmetro para medir a idade possível de Euclides: mesmo que se perceba um relativo exagero na descrição do caso, visto que Mégara está situada a cerca de 40 quilômetros de Atenas, o que dificultaria o trajeto diário, a narração foi costumeiramente tida por fidedigna ${ }^{3}$. Um dos mais velhos companheiros de Sócrates, é bem provável que Euclides tivesse por volta de dezoito anos à época do decreto, o que situaria o ano de 450 a.C. como o ano de seu nascimento ${ }^{4}$. Segundo outros dois testemunhos diversos, é possível dizer que nosso filósofo megárico viveu até os anos de 369 e 366 a.C. ${ }^{5}$

O que ressoa emblemático, no entanto, é sua determinação em seguir durante a noite até Atenas, travestido de mulher para não ser reconhecido, a fim de ouvir as lições de Sócrates madrugada adentro, sem qualquer temor pela morte, ao contrário do que os filósofos estavam a fazer à época de Tauro (T1). Não surpreende apenas o fato de haver certa disposição de Sócrates em se exercitar na filosofia após o anoitecer, o que nos faz lembrar do Banquete de Platão e de sua rijeza referida ao final de uma noite regada a vinho e a discursos. Mas sobretudo a coragem de um homem disposto a desafiar duas cidades em guerra para ouvir seu mestre falar, uma coragem que serve, nas palavras de Tauro, de exemplo bom e saudável (aliis bonis multis salubribusque exemplis) para exortar os mais jovens à filosofia, mais de três séculos depois. Como diria supostamente o Xenofonte das Cartas Socráticas, "Euclides e Térpsio são dois homens muito nobres e bons, além disso,

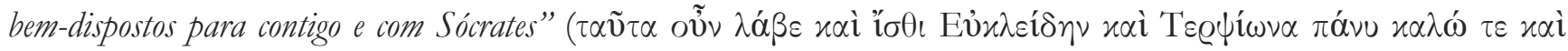

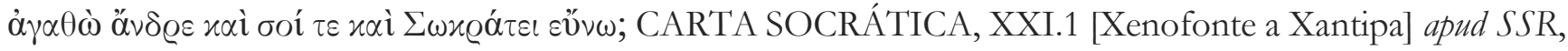
II.A.6) ${ }^{6}$

\section{0 amante de debates erísticos}

A dedicação de Euclides ao exercício filosófico na companhia de Sócrates parece estar muitas vezes

2 Sobre o acontecimento em questão, ver DOVER, 1966, p. 203-209.

3 Cf. MULLER, 1985, p. 96.

${ }^{4}$ Cf. MÁRCISO, 2012a, p. 47, n. 102.

5 Ver GARDELLA, 2015, p. 32.

6 Vale notar que o próprio Platão se refere sempre a Euclides ao lado de Térpsio, tanto em Fédon (59c) como na cena inicial do Teeteto. Sobre a cena do Teeteto, ver ALENCAR (2018). 
vinculada ao apreço por discussões dialéticas ou erísticas - como serão nomeadas por Platão e Isócrates aquelas disputas verbais por meio de perguntas e respostas com vistas a derrubar o lógos do adversário - do qual nos dão notícias diversos testemunhos acerca da formação da 'escola' megárica, que recebeu esse nome exatamente pela referência a Euclides. Não é menos importante destacar de que maneira o próprio Sócrates fora tomado muitas vezes como um apaixonado por discursos e por discussões ${ }^{7}$. Em um passo de Diógenes Laércio, encontramos não apenas a proximidade que parecia haver entre mestre e discípulo, mas igualmente a certeza de que essa familiaridade foi o que permitiu a Sócrates lhe avançar certa crítica, ao indicar ao companheiro de que modo aquele seu apreço pela prática erística rebaixava sua própria condição de filósofo.

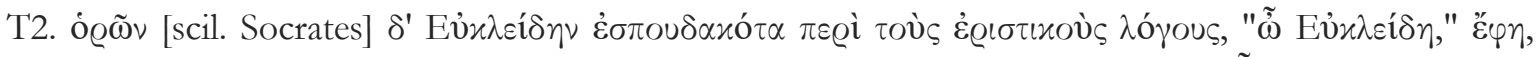

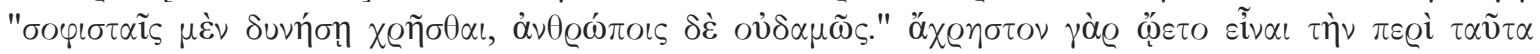

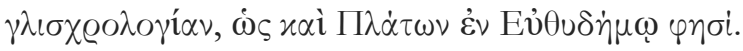

Ao ver Sócrates que Euclides dedicara-se com seriedade aos discursos erísticos, disse-lhe: "Euclides, poderás usá-los com sofistas, jamais com homens", pois cria que a argumentação fundada sobre esses temas era debilitante, como também disse Platão em Eutidemo. (DL, II.30; SSR, II.A.3)

Essa paixão de Euclides pelos diálogos erísticos ressoa alguma coisa de seu exercício como autor de diálogos. O interessante testemunho de Platão, que o retrata ao início do diálogo Teeteto preocupado com a fidelidade da narrativa que estava a fazer da conversa que Sócrates tivera com o jovem Teeteto, ilustra um daqueles momentos do exercício de rememorar a que Rossetti se referia. "Sempre que ia a Atenas, interrogava Sócrates sobre o que eu não me recordava e, ao retornar [para Mégara], corrigia a obra. Foi desse modo que consegui escrever

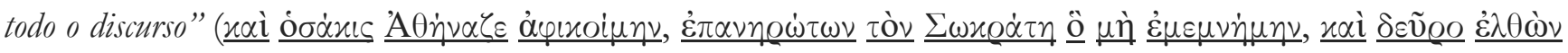

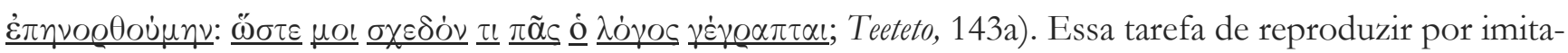
ção a narração das conversas socráticas, incentivada pelo próprio Sócrates, parece esbarrar em uma dificuldade de Euclides em lembrar-se da conversa - no que o testemunho de Platão, de certo modo um tributo ao amigo de Mégara (num dos poucos diálogos em que o líder da Academia dá voz a outros socráticos), não faz senão denunciar a prática escrita do megárico como um recurso devido à sua fraca memória. Era, por certo, uma denúncia, caso tomemos em conjunto a crítica à escrita feita por Platão no Fedro (274b).

Essa paixão de Euclides pelos discursos, poderíamos dizer, contenciosos é parte de uma formulação filosófica que ainda veremos com vagar. Por ora, seria importante recolhermos algumas notícias trazida pelas conhecidas Cartas Socráticas - espécie de recriações fruto de exercícios retóricos postos em prática ao longo dos anos posteriores ao período em que de fato viveram as personagens que nelas figuram. Esse caráter de recreação, segundo a avaliação de Mársico, não impede que as tomemos como vias de acesso para compreendermos as formas pelas quais a segunda sofística concebia as relações entre os socráticos, já que o período entre a atuação de ambos os grupos era relativamente próximo ${ }^{8}$. Partindo dessa avaliação, reunimos alguns

\footnotetext{
7 Cf. a alegação feita nas acusações em Apologia de PLATÃO, da qual Sócrates pretende se livrar, embora ele mesmo apresente os jovens seus imitadores como ávidos em refutar os outros (23c). Mesmo Isócrates pretende se livrar desse tipo de acusação (Antídosis, §56), denunciando os demais socráticos por serem mais apropriadamente assim considerados. PLATÃO por vezes fala-nos da paixão de Sócrates por discursos, por exemplo em Fedro, 228b-c (Toũ

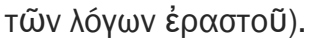

8 Pois aqueles que criaram as Cartas não só tinham mais acesso aos escritos dos socráticos, como também realizavam seus exercícios tendo em vista passarem-se por eles, o que condiciona ao menos o teor das recriações em uma proximidade interessante com a atmosfera do grupo socrático. Acerca dessa argumentação desenvolvida sobre o assunto, ver MÁRSICO, 2012a, p. 77-89.
} 
elementos para a reconstituição possível dos momentos vivenciados pelo grupo socrático após a morte do mestre. Num primeiro texto, testemunha-se a importância de Euclides junto ao grupo que, instalado em Mégara a seu convite, parece ter realizado um intercâmbio criativo dos Lógoi Sokratikoí, em uma fase de experimentações que dá mostras de um convívio inicial cujo propósito maior vinha circunscrito ao exercício da escrita em comum.

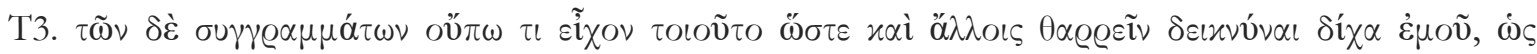

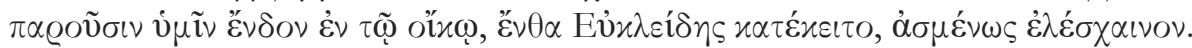

Dos meus escritos, contudo, não encontrei um que pudesse me animar a mostrá-lo a outros sem minha assistência, como conversei alegremente com vocês, quando estavam na casa onde Euclides permanecia confinado. (CARTA SOCRÁTICA, XXII.1 [Ésquines (?) a Xantipa] apud SSR, II.A.7, FS. 64)

O que vale a pena ressaltar aqui, dentre as muitas alusões sugeridas pela passagem, é o que poderia configurar uma aplicação do grupo socrático em trabalhar, em conjunto, aquela chamada unidade dialógica $(\delta i \dot{\alpha} \lambda \varepsilon \xi \varsigma)$ do procedimento de refutação praticado pelo mestre, com destaque para a cena megárica enquanto lugar de exercício coletivo de criação e análise. Nosso próximo testemunho oferece, se for possível confiar, uma compreensão não apenas da paixão do grupo socrático pelos discursos dialógicos, mas também da relevância a que me referi antes, ao propor uma atmosfera intelectual em Mégara voltada diretamente para o intercâmbio daquela diálexis socrática, reconstruída deliberadamente com fins memoriais e de exercício filosófico - indicando inclusive a relevância de Platão enquanto criador de Lógoi Sokratikoí.

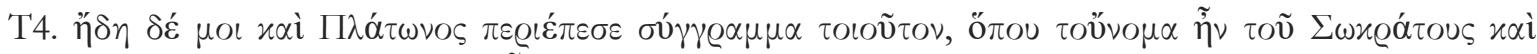

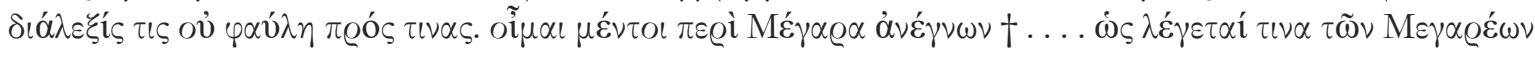
$\tau \tilde{\omega} \nu \tau 0 เ o v ́ \tau \omega \nu$.

Precisamente agora me chegou um escrito de Platão nesse estilo, onde se encontrava o nome de Sócrates e a sua elocução em nada medíocre. Creio, ademais, que eu tenha lido algo parecido em Mégara... segundo dizem, a alguns dos megáricos. (CARTA SOCRÁTICA, XV.2 Xenofonte a Euclides e Térpsio (?) apud SSR, II.A.8) ${ }^{9}$

O que havíamos indicado de início parece agora se esclarecer melhor. Agregar o testemunho do exílio com o da referência a Mégara para um esforço literário em retratar os diálogos de Sócrates em grupo e com finalidade de exercício filosófico traduz o que chamamos de exemplo a ser seguido em Euclides, e foi o que levou Rossetti ${ }^{10}$ a entrever a possibilidade de que tal encontro à casa de Euclides tivesse sido o momento responsável em motivar a chamada literatura socrática com o intuito de forjar uma defesa da memória do mestre, a partir do seu próprio modo de filosofar retratado textualmente por aquelas unidades dialógicas. Supor uma unidade intencional dessa magnitude é, sem dúvidas, exercício de conjectura, não isento de fundamento, embora boa parte das especulações acerca do fenômeno tenha sido sugerida pelas Cartas Socráticas. Rossetti

\footnotetext{
${ }^{9}$ A Carta em questão traz ainda, imediatamente antes desse passo citado, uma referência valorosa acerca do convívio e do exercício de escrita dos socráticos, mas que não a encontramos em grego, e por isso ela vai citada em tradução nossa feita a partir da tradução de MÁRSICO (2012a, p. 160-61): "Parece-me que teremos realmente que redigir aquilo que Sócrates fez e disse. Poderia ser esta sua melhor defesa agora e no futuro, já que não discutimos no tribunal, senão relatando a virtude desse homem durante toda sua vida. Sustento que cometeríamos um erro contra nossa amizade em comum e, como dizia Sócrates, contra a verdade, caso não escrevamos com prazer. "
}

10 Cf. ROSSETTI, 2015, p. 43ss. 
enfocou, para demonstrar essa unidade de intenção, o teor apologético e a técnica de composição dos textos como seus sintomas mais claros. Mársico, em concordância com o traço de originalidade da criação do gênero dos Lógoi Sokratikoi apontada por Rossetti ${ }^{11}$, faz acrescentar a situação de exílio em Mégara como momento de consciência do grupo socrático em vista de se situarem frente à responsabilidade pela defesa da memória de Sócrates. Acredito improvável que essa unidade de procedimento, perceptível inclusive na forma de composição dos Lógoi Sokratikoí, tenha se dado por acaso. Ao que tudo indica, essa intenção nasceu às expensas de Euclides.

Não que tenha sido o caso de o megarense haver elaborado o padrão das conversas socráticas, o que se poderia sugerir pelo Teeteto, mas o momento do exílio deve ter representado para eles a tentativa de estabelecerem um compromisso junto à memória do mestre, em vista de resgatá-la dos traços negativos sob os quais a acusação a havia enquadrado e a condenação, ratificado. Esse padrão ou essas unidades miméticas das conversas de Sócrates é naturalmente anterior a essa contenda, porque procede do próprio Sócrates em vida, aparecendo inclusive na poesia cômica. O que fez a literatura dos socráticos foi dar corpo a diálexis socrática, inserindo-a na cultura ateniense por meio da originalidade de uma literatura que justificava o mestre como um filósofo, distinto de tudo o mais que fora visto em Atenas. O retorno do exílio de parte dos socrátcos à cidade que condenou Sócrates, pode-se conjecturar, foi seguido da maior enxurrada de livros que a pólis democrática de Anito e Meleto jamais vira - talvez nossa época não haja visto fenômeno literário equivalente ${ }^{12}$.

\section{Sobre a dita "escola megárica" e o caso da influência eleata.}

Bem mais do que interessados no desenvolvimento posterior e tardio da chamada "escola" de Mégara, nossos olhos devem voltar-se para Euclides ele mesmo, enquanto aluno e discípulo de Sócrates, para podermos entrever o que há do mestre no megárico. Contudo, um olhar atento sobre os prosseguimentos megáricos daquilo que Euclides teria iniciado ajuda-nos a recompor as teses fundamentais defendidas pelo líder da "escola", sobretudo porque dele nada nos sobrou a não ser notícias esparsas. Diferentemente de Sócrates, de quem nada temos porque nada escreveu, Euclides parece ter sido um escritor de diálogos esmerado e atencioso, ao que dele retrata Platão no Teeteto (143a). Igual a ele no seio dos megáricos, só Estílpon, provável aluno direto do líder megárico e que acabou por se tornar mais famoso que o mestre (DL, II.113).

Digo 'provável' aluno porque um primeiro contato com os estudos sobre os megáricos nos deixa perceber quão problemática é qualquer compreensão das sucessões entre figuras no seio dos achegados a Euclides. A começar pela própria existência da "escola" megárica, como algo similar ao que se vê na escola de Isócrates ou na Academia de Platão. Assumiremos aqui a perspectiva de Gardella (2015), que considera os megáricos como um 'grupo' ou uma 'linha de sucessão' (haíresis) antes de serem uma 'escola' (skholé) em sentido acadêmico, isso pelas seguintes razões ${ }^{13}$ : os termos escola e sucessão foram amplamente utilizados por doxógrafos sem um rigor referencial, além de simplesmente fazer derivar uma figura de outra por certas

11 MÁRSICO, 2012a, p. 79-84.

12 Acerca do impacto publicitário da literatura socrática no retorno ao exílio, ver ROSSETTI, 2015, p. 19-32.

13 Cf. GARDELLA, 2015, p. 35-41. 
afinidades de pensamento (2015, p. 39-40) ${ }^{14}$; a denominação de megáricos, entretanto, aparece em Aristóteles (Metafísica, IX, 3, 1046b 29) e outros como uma denominação comum ao grupo, mesmo para se referir aos que não nasceram em Mégara, porém estavam na linha de pensamento proposta, e na atividade exercida, por Euclides (2015, p. 40).

A autora nos leva a perceber que esse tratamento dedicado ao grupo megárico, ao longo dos estudos sobre sucessão filosófica desde Aristóteles, insiste em alocá-lo ou sob a influência principal das doutrinas eleatas, ou sob a de Sócrates. Os que se posicionam pela aproximação de Euclides às teses defendidas por Parmênides, Zenão e Melisso, mesmo que a entendam tão-somente como uma influência de tipo teórica, destacam, no pouco que sabemos sobre o líder do grupo megárico, o papel que a doutrina do Ser e do Um realiza para uma compreensão do que é o Bem ${ }^{15}$. A fonte principal desta interpretação, além da conhecida passagem de Diógenes Laércio citada mais à frente (T8), está num trecho de Cícero que indica o Bem como Uno e o apresenta como opinião central da linha de sucessão que procederia de Xenófanes até os megáricos.

T5. Megaricorum fuit nobilis disciplina, cuius scriptum video princeps Xenophanes, quem modo nominavi, deinde eum secuti Parmenides et Zeno (** itaque ab is Eleatici philosophi nominabantur), post Euclides Socratis discipulus Megareus, a quo idem illi Megarici dicti, qui id bonum solum esse dicebant quod esset unum et simile et idem semper; hi quoque multa a Platone.

A escola dos megáricos foi célebre. Seu iniciador, segundo o que li, foi Xenófanes, a quem mencionei antes, seguindo-o logo Parmênides e Zenão (pelos quais esses filósofos foram chamados 'eleáticos'), depois Euclides de Mégara, o discípulo de Sócrates, a partir de quem se lhes deu o nome de megáricos. Diziam que é bom apenas o que é uno, sempre similar e igual a si mesmo. Também tomaram muito de Platão. (CÍCERO, Acadêmicos primeiros, II.42.129 apud SSR II.A.31)

Esta, que ficará conhecida como "posição tradicional”, entende a preocupação daqueles conhecidos megáricos como sendo o ápice, por assim dizer, da tese defendida acerca da unidade do Ser. Segundo todas as fontes que nos permitem verificar as datas de atuação das principais figuras aqui apontadas, não haveria nenhum modo de fazer com que Euclides tivesse tomado lições quer de Parmênides, quer de Zenão ou Melisso, e isso nos impõe que a pretensa sucessão entre eles tenha sido tão-somente na esfera teórica ou doutrinal $^{16}$ - o que deixa a possibilidade de ser esta sucessão fruto de construção posterior dos testemunhos sobre ela. Mesmo a própria existência de uma escola eleata foi, sobretudo com Cordero, posta em questão como provável criação platônica ${ }^{17}$. O que não deixa de surpreender é a menção à suposta influência exercida pelo próprio Platão sobre Euclides e os megáricos, relação que gira em torno ao problema das Formas - analisado melhor logo à frente. O próximo trecho, na esteira das sucessões aferidas por Cícero, acrescenta novos detalhes a esse núcleo teórico:

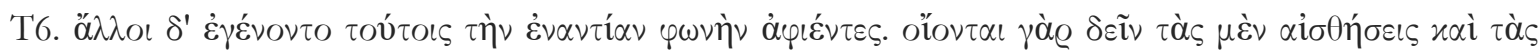

14 A própria sentença, recolhida por DIÓGENES LAÉRCIO, em que Diógenes, o cínico, menciona a 'escola' (skholé) de Euclides (DL, VI.24; SSR, II.A.28; FS, 49) parece seguir esse uso mais lato do termo.

15 Dentre os muitos estudiosos a defenderem essa posição, destacamos HEGEL, 1955, p. 105; ZELLER, 1877, p. 250; DROZDEK, 2005, p. 27, 29; e MÁRSICO, 2012b, p. 18-26.

16 O levantamento de datas e possibilidades do encontro entre as figuras mencionadas encontra-se resumido em GARDELLA, 2015, p. 42-43.

${ }^{17}$ A opinião de CORDERO, em suma, é a de que Platão, em Sofista, criou a unidade relativa aos pensadores eleatas a partir de uma suposta defesa comum, feita pelos adeptos de Parmênides, do Ser (éon) como Uno. Ver 1991, p. 93 124. 


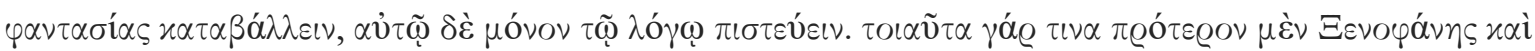

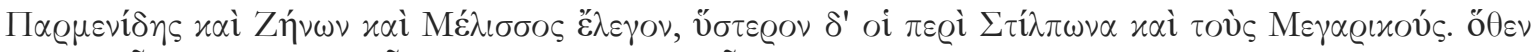

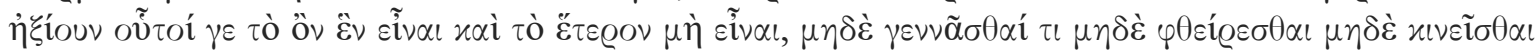

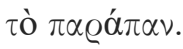

Mas apareceram outros que diziam o contrário, pois criam que se deve desdenhar das percepções e das representações, e confiar apenas no raciocínio por ele mesmo. Com efeito, isso era dito primeiro por Xenófanes, Parmênides, Zenão e Melisso, e também depois os seguidores de Estípon e dos megáricos. Por isso, afirmavam que o ser é uno e que o seu contrário não existe, nem gera algo, nem se destrói, nem se move em absoluto. (ARISTOCLES, Sobre a filosofia, frag. 2, [segundo Eusebio, Preparação Evangélica, XIV.17.1, p. 756 b-c] apud SSR, II.O.26)

Mais uma vez, o grupo megárico aparece vinculado à tradição eleata - ou daqueles que defendiam o princípio do Ser-Uno - tendo em destaque, porém, não mais a figura de Euclides, e sim a de Estílpon, como a possível referência para as três teses que vinculariam ambas as tradições: a confiança no raciocínio, a unidade do ser e a inexistência do seu contrário. Isso porque no grupo megárico não parece haver unanimidade quanto a essas teses, senão aquela sobre a confiança no pensamento que implica desconfiar do sensível ${ }^{18}$. Uma tal confiança, entrementes, pauta-se inclusive no descrédito com a linguagem ordinária, tão enganosa quanto as percepções. É por esse motivo que Aristóteles, parecendo dirigir-se contra teses de cunho megárico em Metafísica IV, chama seus adeptos de homens ávidos em "procurar a razão em tudo"19. Uma razão que se sustenta apenas verbalmente, dirá Aristóteles, pelo prazer da discussão, ora sustentando uma verdade, ora seu oposto, semelhantemente ao que fora retratado por Platão em Eutidemo. Pois também ali o que se vê é a dialética megárica em exercício, uma dialética tornada erística, dirá Berti, por basear-se naquela univocidade do ser sustentada por Parmênides e refutada por Górgias ${ }^{20}$. A negação do conhecimento sensível a partir de discursos capciosos será posteriormente o exercício mais comum da tradição iniciada por Pirro, discípulo de Bríson, filho de Estílpon (DL, IX, 61).

Ao que parece, Euclides ausenta-se no referido testemunho pelo fato de não haver sustentado teses como essas três. Veremos que, na realidade, o princípio de unidade euclidiano encontra-se no Bem, sendo não apenas inexistente o seu contrário como também enganosa a linguagem que o apresenta com nomes variados e diversos (T8). De fato, não se desconhece a relevância do tema do Bem para a corrente dos socráticos, de modo que, frente a essa posição "tradicional" com relação ao grupo de Euclides, que o vincula aos eleatas, defender-se-á os megáricos como fundamentalmente socráticos. Essa defesa será feita por Gardella, na sequência dos estudos de Von Fritz e de Giannantoni, para citar os mais importantes ${ }^{21}$. E no embate entre as duas perspectivas, o que aparece como decisivo está em ver Euclides ou como um dialético-erístico de preocupações ontológicas (segundo a visão “tradicional”), ou como um filósofo de preocupações éticas, cuja investigação trata da questão da linguagem a fim de mostrar sua perigosa ambiguidade para a ação

18 Como haviam indicado ZELLER, 1887, p. 259; MULLER, 1985, p. 46-47; 83-110. Embora ambos avancem bem mais, ao sugerir que os megáricos atribuíam ao pensamento a possibilidade de conhecer as determinações permanentes da realidade.

19 Cf. ARISTÓTELES, Metafísica, 1012 a21. Reale, em nota da sua edição crítica, não deixou de notar que Ross, aqui, acreditava estar Aristóteles referindo-se a Antístenes, o que não impede de haver a possibilidade da referência aos megáricos, já que, como analisou BERTI, ambos socráticos defendiam teses similares: 2013, p. 91-110.

20 Cf. BERTI, 2013, p. 50-53; 96-98. Sobre o Eutidemo como retrato de atitudes megáricas, ver DORION, 2003, p. 35 50.

${ }^{21}$ Cf. GARDELLA, 2014, p.33-2, p.19-37. Ver também VON FRITZ, 1931, p. 707-24; GIANNANTONI, 1990, vol. 4, p. 369, 44-50. 
humana.

Essa última posição observaremos agora. Pois, de fato, aos autores que procuram tomar a influência socrática como determinante, não aparece outro indício senão junto a preocupação ética fundamentada por Sócrates. E antes de aceitarmos como dada essa preocupação no seio do socratismo, podemos remontá-la, ao menos, ao testemunho de Isócrates - pois ele havia proposto uma crítica aos socráticos por defenderem que as virtudes são uma, obtendo-a por conhecimento (Contra os Sofistas, \$1-6) e para isso se lançavam em exercícios erísticos que, aos olhos de Isócrates, eram inúteis. O que se poderia nomear então de preocupação ética é, segundo a opinião de Isócrates, uma defesa da unidade das virtudes no conhecimento, que Platão e Xenofonte mostraram ser uma elaboração própria de Sócrates ${ }^{22}$. Tanto a acusação quanto a defesa aqui coincidem no ponto da discórdia, e nesse ponto temos a probabilidade de que o fenômeno do socratismo haja encontrado uma zona temática própria ao mestre. Socrático seria então quem fundamentasse sua investigação na tarefa de definir a areté pelo saber - e Euclides está inserido nessa tradição.

O que soa problemático, na tentativa de compreender o pensamento megárico originado em Euclides, é a suposta defesa da unidade enquanto tese ontológica, e não fundamentalmente ética ou epistêmica. A tentativa de fazer ouvir uma metafísica em Euclides assenta-se sobre aquilo mesmo que a postura "tradicional" defendia, uma espécie de vinculação entre a tese do agathón de Euclides e a do éon eleata. Considerar o Bem como o Ser é o que a própria Gardella desfaz ao enfocar a perspectiva de Euclides a partir de uma preocupação exortativa. A autora não mediu esforços em explicitar o posicionamento megárico, iniciado pelo líder do grupo, valendo-se de testemunhos que aproximam Euclides do tipo de defesa do autodomínio, comum ao círculo de Sócrates ${ }^{23}$. O texto a seguir é um exemplo.

T7. Euclides dixit: plerosque hominum stultos serviles cibos et servilem vestem fugere, serviles mores non fugere.

Euclides disse: a maioria dos homens é insensata: evitam alimentos e vestimentas de escravos, mas não costumes de escravos. (GNOM. PARIS. LAT. n. 8 apud SSR, II.A.21)

O tipo de texto, em estilo exortativo - a ser inclusive caracterizado por Demétrio como estilo próprio da argumentação de Aristipo ${ }^{24}$-, demonstra estar na diferença entre ser e parecer o engano não só epistêmico, mas sobretudo ético, que se pode sustentar a partir de uma falsa concepção: pois alguém poderia pensar não ser propriamente escravo, mas sê-lo de fato e agir por engano. E trata-se de, para não ser escravo, dizia Sócrates em inúmeros testemunhos, dominar-se a si mesmo ${ }^{25}$. A melhor defesa do socratismo está, em Euclides, não em um corte metafísico, mas antes ético-exortativo. A doutrina do megárico faz ver, por meio do lógos (em dialética), de que modo o Bem-Uno está para além da linguagem e da percepção humanas, assentando-se na concretude do que há de melhor naquilo que devemos desejar e conhecer. É na relação entre ética e dialética que Euclides justificou sua inspiração socrática.

22 Por exemplo, em PLATÃO, Protágoras, 329c-334c e XENOFONTE, Memoráveis, III, 9.

23 GARDELLA, 2015, p. 51-54.

24 Em SSR, IV.A.148, FS, 556, [DEMETRIO, Sobre a elocução, 296]: “Os homens deixam aos seus filhos dinheiro, mas não conhecimento, que confere o necessário a quem o possui. Diz-se que esta era a forma da argumentação aristi-

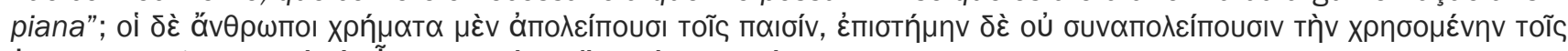

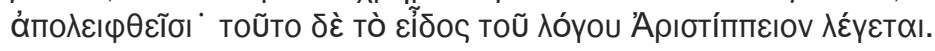

25 Cf. SSR, I.C.186, [ESTOBEU, II.8.29]: “Sócrates dizia que o maior governo é o poder real, mas que o melhor é gover-

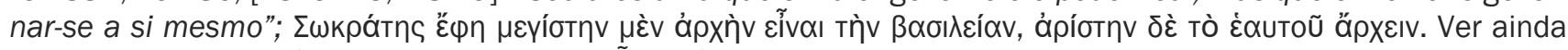
XENOFONTE, Memoráveis, I.5, II.1, IV.5; PLATÃO, Górgias, 491c-e. 


\section{A filosofia socrática de Euclides: Ágathon kai Lógos}

De todas as marcas levantadas pelos comentadores para validar e justificar o peso dos testemunhos que vinculam Euclides ao grupo socrático, a mais decisiva encontra-se na defesa feita, pelo megárico, da tese sobre a unidade das virtudes - mais precisamente, sobre a realidade una do Bem. Em um pequeno trecho de Diógenes Laércio, ficamos conhecendo a indicação de que, para os megáricos, a excelência que é una se chama por muitos nomes ${ }^{26}$. Mas a referência aos megáricos e não a Euclides em pessoa pode suscitar a dúvida em ser de fato esta uma tese euclidiana. A suspeita se desfaz quando o próprio Diógenes nos indica o que seria a formulação fundamental da filosofia de Euclides.

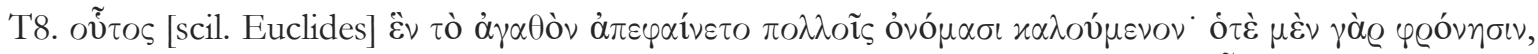

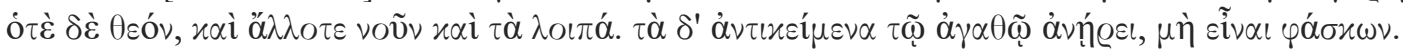

Ele declarava o Bem uno, embora recebesse muitos nomes - às vezes prudência, às vezes deus, ou ainda inteligência, e assim por diante. Rejeitava o que fosse contrário ao bem, afirmando não existir. (DL, II.106; [Hesiquio de Mileto, Sobre os homens ilustres, 27; Arsenio, p. 253.27-254.2]; SSR, II.A.30)

Esta notícia doutrinária repercute aquela já vista na indicação de sucessões, encontrada em Cícero, que vincula o Bem ao Uno, de modo a entender, contudo, que só é bom aquilo que é único e o mesmo sempre, sendo inexistente o seu contrário. O enfoque aqui, a depender do tipo de perspectiva que se adote a fim de alocar Euclides na esteira ou de Parmênides ou de Sócrates, pode recair quer sobre a unidade do que existe, quer sobre a unidade real do Bem. Se não há qualquer indício que nos permita remontar uma unidade do Bem ao círculo dos eleatas, como vimos, parece decorrer da influência socrática a doutrina do agathón relacionada à areté, de tal forma que Gardella, em seu estudo já citado, procurou aferir dos testemunhos que nos sobraram uma espécie de agathología euclidiana.

O primeiro ponto a reter é, pois, a unidade das virtudes, ou do Bem. Uma unidade que se faz afir-

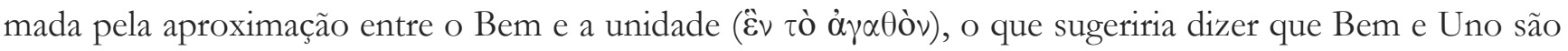
passíveis de predicação mútua, mesmo pela ausência do verbo eînai. De fato, a língua grega elide muitas vezes o verbo de ligação entre o sujeito e seu predicado, mas o cuidado que havia com a linguagem por parte dos megáricos deixa-nos a possibilidade de que seus intérpretes tenham sido provocados a um zelo maior na reprodução das teses de Euclides e do grupo megárico, de tal modo que podemos suspeitar que haja aqui uma distinção entre Euclides e o grupo megárico: o apelo excessivo à impossibilidade da predicação, feito

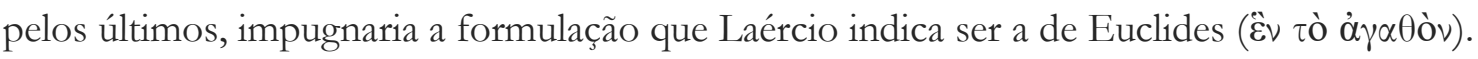

A suspeita não parece infundada. No caso de Estílpon, por exemplo, o mais famoso dos alunos de Euclides, a impugnação da predicação assenta-se sobre a ausência de legitimidade em atribuir a uma coisa algo diferente dela - como quando se diz “o cavalo corre”, afirma-se que ambos, 'cavalo' e 'correr', não são

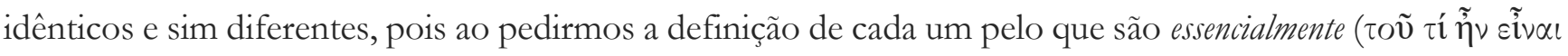
$\tau$ òv $\lambda$ ó $\left.{ } O v^{27}\right)$, não damos a mesma definição para ambos. Sendo distintos, estamos a dizer inadequadamente sobre o cavalo e o correr quando dizemos "o cavalo corre". Quer dizer, ao cavalo não é próprio o correr,

26 DL, VII.161 (SSR, II.A.32): "Não admitia haver muitas excelências, como fazia Zenão, nem a existência de apenas

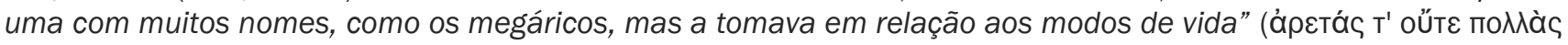

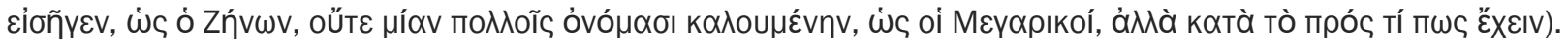

27 Cf. PLUTARCO [Contra Colotes, 22-3.1119 c-1120 b] apud SSR, II.0.29; FS, 305. 
posto que há cavalos que não correm, nem é próprio do verbo 'correr' ser um cavalo a realizá-lo, posto que há outras coisas que correm. Simplício atribui essa tese não só a Estílpon, mas a todo o grupo megárico, em um trecho eivado de uma interpretação difamatória.

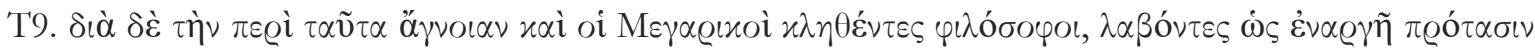

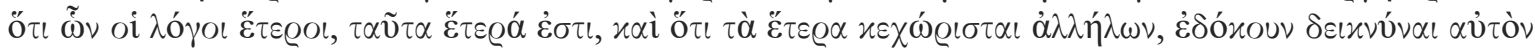

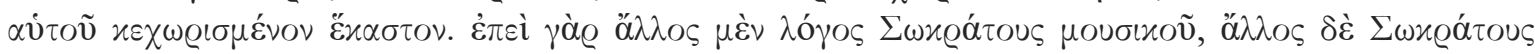

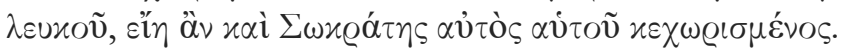

Por ignorância acerca deste assunto, também os filósofos chamados megáricos, ao tomarem como evidentes as premissas de que aquelas coisas cujas definições diferem são também diferentes, e de que as coisas diferentes estão separadas umas das outras, criam que isto provava que cada coisa está separada de si mesma, pois dada a definição de Sócrates músico e outra de Sócrates branco, precisamente Sócrates estaria separado de si mesmo. (SIMPLICIO, Sobre a Física de Aristóteles, 120.12-7 apud SSR, II.O.30)

Em Euclides, no entanto, uma tese como essa só pode ser dita estar em germe, porque a indicação de Laércio (T8) mostra, antes, que o esforço e o cuidado do socrático estava em dar ao discurso a propriedade de falar por contrastes: o bem é uno, embora dito com muitos nomes; e desde que é o bem aquilo mesmo que é, o que lhe é contrário não é. Desse modo, é forçado vincular o líder do grupo megárico a esta tese forte sobre a inadequação da predicação, como ocorre claramente em testemunhos sobre Antístenes, por exemplo. Fato é que uma compreensão acerca do método adequado de uso e de análise da linguagem era comum entre os socráticos ${ }^{28}$. Aquilo que diz respeito à preocupação euclidiana, em especial, alguns outros testemunhos de que dispomos nos induzem a elementos próprios de um maior cuidado com a argumentação, que confere ao pensamento de Euclides um matiz lógico cuja fundamentação assenta-se sobre considerações éticas $^{29}$. É desse tipo o texto que se encontra em Láercio, para quem o megárico desenvolveu críticas pontuais aos esquemas argumentativos comuns à época.

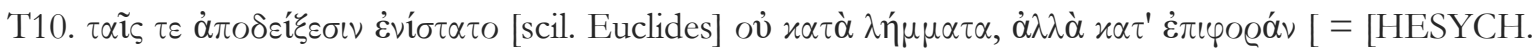

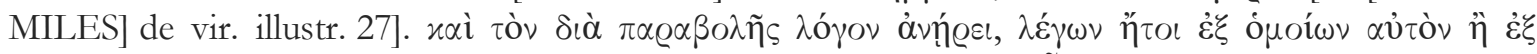

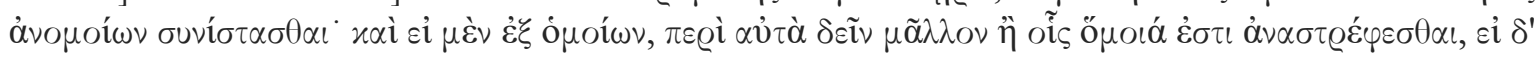

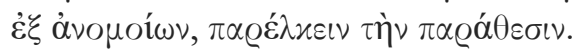

Euclides se opunha às demonstrações não em suas premissas, mas na conclusão. Rejeitava também o argumento por analogia, declarando que o mesmo se baseia em coisas similares e dissimilares: se se baseia em coisas similares, é nestas e não em sua analogia que o argumento deve se ater; se se baseia em coisas dissimilares, então o paralelo é supérfluo. (DL, II.107, Frag. 28 Diels; Arsenio, 254.2-11 apud SSR, II.A.34)

A indicação sobre a refutação euclidiana assentar-se na conclusão de argumentos aproxima o megárico do método dialético criado por Zenão de Eleia. O enfoque do discípulo de Parmênides estava em

\footnotetext{
28 Sendo esse um dos temas incluídos na lista de tópicos socráticos feita por KAHN, 1991, p. 4.

29 "No entanto, notemos que este juízo traz em destaque um aspecto fundamental da posição megárica, ligado à inadequação entre linguagem e realidade: se o bem - seja ou não identificado com o real - é uno, e o dispositivo linguístico é necessariamente múltiplo e variado, as opiniões usuais que refletem essa multiplicidade estariam erradas e poderia também não haver modo de representar a unidade, de modo que a atividade da dialética erística cumpriria a função de chamar a atenção sobre essas limitações, a que, sem encerrar estritamente em um ceticismo, tem com ele pontos de contato importantes em relação com os limites da apreensão e expressão do real." (MÁRSICO, 2012b, p. 54, n. 122).
} 
reduzir as teses assumidas (conclusões de certos raciocínios) a uma sua contradição, método muito usado depois por Górgias e que Aristóteles chamará de redução ao impossivel ou absurdo (apagogé eis ton adýnaton) ${ }^{30}$. Mas a dialética zenoniana, como analisada por Berti a partir do estudo de Migliori ${ }^{31}$, é refutação a partir da consideração unívoca dos conceitos no discurso, pressuposto lapidar do tipo de exercício argumentativo dito erístico. Vemos muitas dessas formas de argumentação no Eutidemo de Platão, Diálogo que, no entender de Dorion, tinha como interlocutores não os sofistas, mas os megáricos ${ }^{32}$. Entende-se agora por qual razão Sócrates havia censurado seu discípulo ao vê-lo dedicar-se com afinco aos ditos discursos erísticos (T2); explica ainda o motivo pelo qual o testemunho de Laércio termina com a menção a um comentário de certo Tímon acerca dos socráticos, para quem não passavam de tagarelas ( $\varphi \lambda \varepsilon \delta o ́ v \omega \nu$ ), no qual Euclides, o contendor

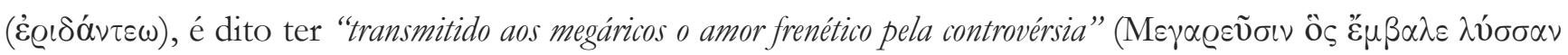

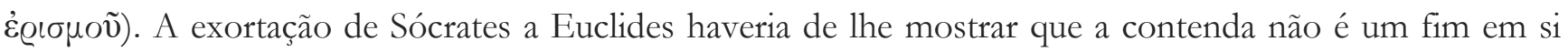
mesma.

A concepção da refutação pela conclusão e a rejeição da analogia são, para Berti ${ }^{33}$, a prova de certo eleatismo sobrevivente em Euclides e no grupo megárico. Tão comuns eram os argumentos por analogia que não cansamos de vê-los retratados por Platão e Xenofonte como forma da argumentação de Sócrates. Já em Aristófanes, a analogia é método socrático eficiente, de modo que propor uma recusa da analogia significava ir contra o próprio método do mestre. O problema da analogia, explica o texto, é similar àquele já referido acerca da formulação de Estílpon, pois não é possível valer-se de algo distinto ao que se deseja mostrar: ou se mostra o que se deseja por ele mesmo, ou se estará a mostrar outra coisa. A famosa alegoria da caverna da República de Platão seria, nesses termos, uma impropriedade. Para Berti, a concepção euclidiana assenta-se sobre a univocidade do ser, tal como a lógica de Parmênides e Zenão, e o motivo pelo qual Euclides rejeitava a analogia pode estar relacionado a um princípio forte da essência de cada coisa considerada isoladamente. Não faltaram os que, desde Schleiermacher, incluíram os megáricos entre os amigos das Formas, apontados no Sofista de Platão (246b, 248a).

Mas antes de se tratar aqui de Formas inteligíveis separadas, o que o testemunho sobre Euclides parece indicar é sua consideração do âmbito inteligível como sendo responsável pela ordem da multiplicidade dos entes no mundo sensível, de tal modo a ser o Bem a realidade una das coisas que não só percebemos, mas sobre as quais falamos, como sendo muitas. Quando Laércio finaliza seu parecer apontando para o fato de que Euclides tomava o contrário do Bem como não existindo, a força da sua argumentação não parece situar o Bem como o modo de ser das coisas, mas antes visa negar o seu contrário. Pode ser que existam coisas distintas do Bem, como há cavalos e há Sócrates, por exemplo; e isso situa a lógica euclidiana como distinta da dos eleatas, por não se tratar aqui de uma concepção da unicidade do Bem, ou seja, o Bem como único tal como o Ser, mas de sua unidade, que significa, em suma, sua realidade Inteligível. O contrário do Bem, quer dizer, aquilo que divide e desordena, é o que não existe. O Bem-Uno não é a única realidade, mas o que a fundamenta, por ser a garantia de ordem à multiplicidade.

Em outras palavras, dizer o Bem é considerar a unidade, enquanto princípio divino ( $\theta \varepsilon$ cóv) de organização racional

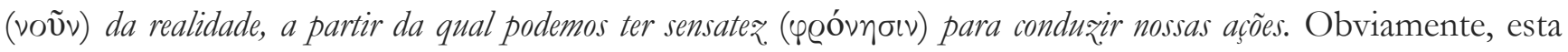

\footnotetext{
30 Cf. as análises de BERTI, 2013, p. 34-37.

31 MIGLIORI, 1984, apud BERTI, 2013, p. 36.

32 Cf. DORION, 2003, p. 35-50. Vale dizer que também haveria referências no Eutidemo contra Antístenes e mesmo contra Isócrates.

${ }^{33}$ Cf. as análises sobre a dialética zenoniana e sua utilização por Euclides e Antístenes, em BERTI, 2013, p. 50-57.
} 
última sentença - que almeja articular numa paráfrase os três termos do que poderia ter sido a tese fundamental da filosofia de Euclides - é deveras conjectural, e assenta-se, como em Gardella, sobre a compreensão dos três conceitos apontados segundo o que sabemos a partir de pensadores anteriores, ou da época de Euclides. O que vale ratificar, em cada um dos termos referidos a Euclides, é o princípio de ordenação como representando o Bem: a boa ordem divina, a boa harmonia dos entes, a boa condução da vida ${ }^{34}$. No fim, eles são manifestações distintas do mesmo Bem. É o Bem que importa conhecer em qualquer situação, e conhecê-lo é, portanto, agir de modo excelente.

Entretanto, e afora o caráter conjectural da síntese que propus na frase acima, o texto de Laércio restringe-se a aportar a atenção do megarense sobre o caráter dicotômico do Bem e suas variadas formas verbais. Em outra passagem significativa (LACTÂNCIO, A instituição divina, III.12.9 apud SSR, II.A.31; FS, 85), Euclides é dito certamente ter entendido a natureza do Bem supremo, "ainda que não a tenha explicado". A ausência de explicação pode ser tanto por uma recusa a tratar sobre o assunto em forma escrita, similar ao que se diz de Platão em Carta VII, quanto por uma noção de que a linguagem se afasta do real na medida em que torna múltipla a unidade do existente. Porque é próprio ao lógos não apenas particionar o que são as coisas em sua unidade (tornando-as passíveis de ser enfocadas ao menos sob dois aspectos, como sujeito e predicado), mas levar-nos a crer que a realidade é múltipla e não una. Aos olhos euclidianos, parece, o lógos adequado para expressar o Bem era, em último caso, o reverso do lógos, quer dizer, o silêncio. Dito de outro modo, não se deveria dizê-lo, mas vivê-lo.

Pelo que é possível saber, esse foi o motivo de Euclides não apenas compreender a força do tipo de refutação dialógica praticada por Sócrates, mas também desenvolvê-la ao ponto de transformar sua escrita e sua argumentação na melhor maneira de persuadir seu interlocutor a olhar para a unidade ao invés de perder-se na multiplicidade. O discurso não teria senão a função de ser protréptico - e, portanto, não se trata de discursar sobre o Bem, como faz a proposta de Gardella ao defender a doutrina de Euclides como sendo uma agathología ${ }^{35}$. Trata-se, antes, de direcionar-se ao Bem por meio do lógos, livrando-se das concepções enganosas para ater-se cada vez mais ao que há de realidade no desejo humano em agir e conhecer, porque ao desejar agir bem, não buscamos senão o que há de melhor a ser feito. Na esteira do modo de pensar dos gregos, que identificava o bem com o belo, Euclides entende que "entre os homens, agem melhor aqueles que imitam

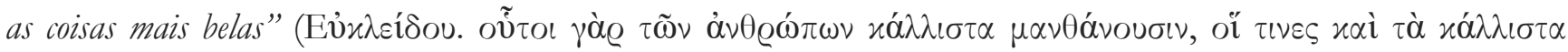
$\mu \iota \mu о \tilde{v} \tau \alpha$; ESTOBEO, II.31.52 [Exc. Juan Damasceno, II.13.52] apud SSR, II.A.18, FS, 74). A educação que imita o belo era, diria o socrático Ésquines, uma educação erótica. O lógos, em sua funcionalidade educativa, deve ser usado para exortar os homens ao melhor caminho, o da imitação - ou de nada valeria a vida.

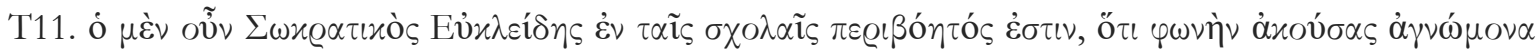

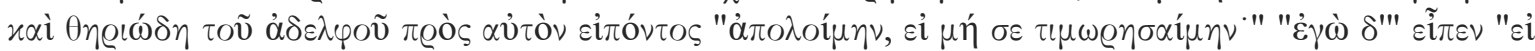

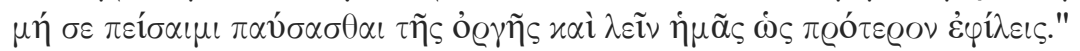

O socrático Euclides ficou famoso entre as escolas porque, ao escutar a voz insensata e feroz de seu irmão que dizia "que me matem, se eu não puder me vingar de ti", contestou-o: "e a mim, se não puder te persuadir a terminar com a ira e a querer-me como me querias antes" (PLUTARCO, Sobre o amor fraterno, 18, p. 489d apud SSR, II.A.15)

\footnotetext{
34 "Todos os nomes que Euclides evoca da tradição precedente referem-se a entidades que cumprem funções de organização cósmica, comprometidas com a totalidade do que existe. À luz dessas considerações, pode-se aventar que o bem euclidiano possuía uma função semelhante, vinculada não só à esfera ética humana, mas também à ordenação racional necessária do real"; GARDELLA, 2015, p. 58-9.
}

35 GARDELLA, 2015, p. 54ss. 
O exemplo euclidiano estava realizado. Ao pensar que as condenações dirigidas a ele, em ser um tagarela preso a futilidades argumentativas, tinham sido direcionadas também a Sócrates, Euclides deve ter pensado estar no caminho certo. Sua paixão pela contenda era na verdade o que motivou Diógenes, o cínico, em um jogo de palavras tipicamente megárico, a dizer que a escola (skbolé) de Euclides não era senão uma "bílis" (kholé) ${ }^{36}$. Contudo, o ímpeto do lógos em dialetizar a fim de refutar as pretensões de saber do interlocutor só poderia ser bem-visto por aquele que estivesse realmente interessado em fugir da própria escravidão a fim de tornar-se prudente. Mas a maioria, fincada nas aparências, acaba por viver como se dormisse. O sono, irmão gêmeo da morte, é tema de um texto cuja menção parece dizer respeito inclusive ao tipo de escrita de Euclides.

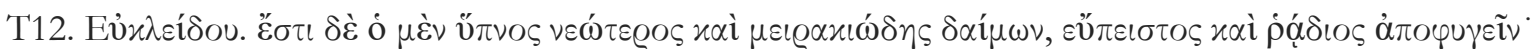

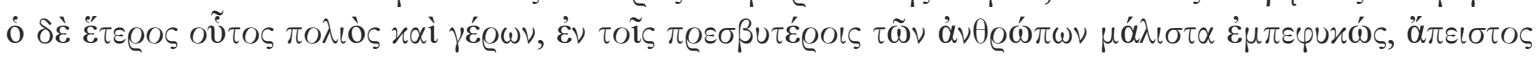

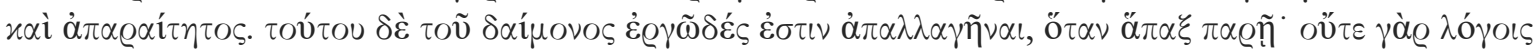

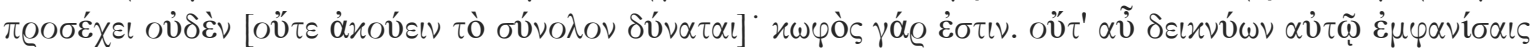

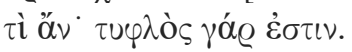

De Euclides. O sono é um daimon mais novo e mais jovem, fácil de persuadir e de escapar. Mas o outro é ranzinza e velho, é totalmente conatural aos anciãos entre os homens, sendo difícil de persuadir e implacável. É problemático libertar-se deste daímon, quando se apresenta uma única vez, pois não presta nenhuma atenção aos discursos nem pode escutá-los no geral, porque é surdo. Por sua vez, tampouco poderia manifestar-se por gestos, porque é cego. (ESTOBEO, III.6.63 apud SSR, II.A.11)

Eis um dos mais enigmáticos testemunhos sobre o pensamento de Euclides, tão enigmático que não se pode esperar saber muito de um trecho deslocado assim de seu contexto ${ }^{37}$. A lição, em contrapartida, não parece ser duvidosa: contra o fim implacável da vida, nem mesmo o poder do lógos é capaz de vitória. E Euclides, sabendo disso, conhecia seus limites. Porque de fato o socrático, testemunhando como digna de valor a exortação que Sócrates lhe dirigira para que contivesse sua býbris erística (T2), não pôde insistir no caminho de um Eutidemo ou de um Dionisodoro sem parecer, em sua própria prática, amar a contenda mais do que a excelência que o mestre lhe havia ensinado. Acima ou além do lógos, ele sabia, está o Bem que governa a todos, e para o qual é necessário voltar-se a fim de agir de modo excelente. Por esse motivo, Euclides, apesar dos megáricos, não se perdeu na erística, mas pode ser dito, com toda a força da palavra, um socrático digno de seu exemplo.

\section{Considerações finais}

De todo modo, o testemunho exemplar de Euclides de Mégara aponta para aquilo que se pode identificar como sendo a preocupação socrática por excelência: aquela que vincula o saber ao que há de melhor a ser feito. Em Euclides, o Bem situa-se em referência a esse saber, como princípio que unifica a realidade e que se faz objeto erótico das ações humanas. Chamamos essa preocupação de uma ética, que de

\footnotetext{
36 DL, VI.24 (SSR, II.A.28, FS, 49).

37 MÁRSICO (2014, p. 55, n. 126) não deixou de pontuar a importância do fragmento, ao mesmo tempo em que lamenta o pouco que podemos saber sobre o contexto do qual foi retirado. O que vale a pena mencionar, diz ela, referese à dúvida levantada ao se comparar este testemunho com aquele outro sobre a recusa de usar analogias, pois trata-se aqui da analogia entre dois gênios, o do sono e o da morte, rotineiramente trabalhados pela tradição grega desde Homero (Ilíada, XIV.231).
} 
certa forma aponta para aquilo que Sócrates entendia como sendo o território das investigações discursivas como libertação das falsas opiniões a fim de fundamentá-las pelo recurso à alma do ouvinte como responsável por saber e agir.

A exortação à unidade do Bem em Euclides era obtida pelo esforço e pela dedicação à arte da controvérsia, dita erística, mas que se apresenta como dialética, pela finalidade ética que a orienta. Frente à retórica acusatória de um Polícrates, que havia feito de Sócrates um corruptor dos jovens, Euclides o tornara modelo de educação, como fez igualmente Isócrates em Antídosis, embora contrapondo-se à proposta erística que este socrático megarense entendia ser o caminho exemplar da exortação ao cuidado de si mesmo. Se a brakhylogía socrática era desprezada como inútil por Isócrates, Euclides foi exemplar na aplicação e na dedicação a esse caminho em direção à excelência. Essa era a sua melhor defesa da diálexis socrática como fundamento ético e educativo para a alma humana.

\section{Referências}

\section{Abreviaturas das edições utilizadas:}

[DL] Diógenes Laércio. Lives of Eminent Philosophers. Ed. R.D. Hicks. Cambridge. Harvard University Press. (First published 1925) (site Perseus), 1972.

[FS] Mársico, C. Filósofos Socráticos: Testimonios y Fragmentos, vol. I e II (traducción, introductión e notas). Buenos Aires, Losada, 2014.

[SSR] Giannantoni, G. Socrates et Socraticorum Reliquae, 4 vols. (edição, introdução e notas) Nápoles, Bibliopolis, 1991.

\section{Demais bibliografias:}

ALENCAR, C. (2018) “A imagem do filósofo: o Teeteto de Platão e o método de Sócrates”. Griot, v.18, n.2, p.129-142.

ARISTÓTELES. (2014) Metafísica. 3 vols. Tradução, introdução e notas da edição italiana de Giovani Reale por Marcelo Perine. São Paulo: Loyola.

BERTI, E. (2013) Contradição e dialética nos antigos e nos modernos. São Paulo, Paulus.

CAMBIANO, G. (1977) “Il problema dell'esistenza di una scuola megarica”. In Giannantoni (orgs.), Scuole socratiche minori e filosofía ellenistica, Bologna, p. 25-53.

CORDERO, N. (1991) “L'invention de l'école éléatique (Platon, Sophiste 242d)". In Aubenque (org.), Études sur le Sophiste de Platon, Napoli, Bibliopolis, p. 93-124.

DORION, L-A. (2003) “Euthydème et Dionysodore sont-ils des Mégariques?”. In T. Robinson; L. Brisson (eds.), Plato. Euthydemus, Lysis Charmides. Proceedings of the V Symposium Platonicum, Sankt Augustin: Academia Verlag, p. 35-50.

DOVER, K. J. (1966) “Anthemocritus and the Megarians”. American Journal of Philology 87.2, Baltimore, p. 203-209.

DROZDEK, (2005) “Euclides of Megara: God = Phronesis = The Good". Acta Antiqua Academiae Scientiarum Hungaricae, 45, p. 27-34.

GARDELLA, M.

. (2013) "Conflictos socraticos en el Eutidemo: la crítica platónica a la dialética megárica". Argos, 36, p. 45-64.

. (2014) “Euclides de Mégara, filósofo socrático”. Ágora - Papeles de Filosofía, 33.2, p. 19- 
37. torial Rhesis.

. (2015) Las críticas de los filósofos megáricos a la ontología platónica. Buenos Aires, Edi-

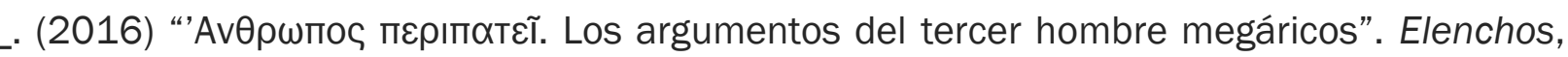
anno XXXVII, fasícolo 1-2, Nápolis, Bibliopolis, p. 69-94.

GILLESPIE, C.M. (1911) “On the Megarians”. Archiv für Geschichte der Philosophie, vol. 24, no. 2, pp. 218-241

HEGEL, G. W. F. (1995) Lecciones sobre la historia de la filosofia, vol. Il (tradução española de W. Roces). México, Fondo de Cultura Económica ( $1^{\circ}$ ed. Alemana 1833).

ISOCRÁTES. (1982) Discursos. Introducción general de Juan S. Codoñer, traducción y notas de Juan M. G. Hermida. Madrid: Gredos.

MÁRSICO, C.

- (2010) Zonas de tensión dialógica: perspectivas para la enseñaza de la filosofia griega. Buenos Aires, Livros del Zorzal.

Miluno.

- (2012a) Cartas, Sócrates y los socráticos (tradução, introdução e notas). Buenos Aires:

. (2012b) “Megaric Philosophy Between Socrates' Influence and Parmenides' Ghost”. Parmenides, Venerable and Awesome, Cordero (org.). Parmenides Publishing, p. 353-362.

. (2014) Filósofos Socráticos, Testimonios y fragmentos, Vol. I e II (tradução, introdução e notas). Buenos Aires: Losada.

MULLER, R. (1985) Les Megariques: Fragments et témoignages. Paris, J. Vrin.

PLATÃO.

. (2007) Diálogos I - Protágoras, Teeteto, Sofista. Tradução de Edson Bini. Bauru: Edipro.

. (2011a) Eutidemo. Tradução, apresentação e notas de Maura Iglésias. Rio de Janeiro: Ed.

PUC-RIO; São Paulo: Loyola.

. (2011b) Fédon. Tradução e introdução de Carlos Alberto Nunes. Belém: Ed. UFPA

. (2011c) Fedro. Tradução e introdução de Carlos Alberto Nunes. Belém: Ed. UFPA

ROSSETTI, L. (2015) O diálogo socrático. São Paulo, ed. Paulus.

VON FRITZ, K. (1931) “Megariker”. Pauly-Wissowa Realenzyklopädie der classischen Altertumswissenschaft, supl. V, Stuttgart, Metzler, p. 707-24

WHEELER, S. (1983) “Megarian Paradoxes as Eleatic Arguments". American Philosophical Quarterly, Vol. 20, No. 3, p. 287-295.

XENOFONTE. (2009) Memoráveis. Tradução de Ana Elias Pinheiro. Coimbra: CECH.

ZELLER, E. G. (1877) Socrates and the Socratic Schools (tradução de O. J. Reichel), London, Longmans, Green and Co. (1 $1^{\circ}$ ed. alemana 1844-52)

Artigo recebido em: 07 de julho de 2019

Artigo aceito em: 22 de julho de 2019 